\title{
The Influence of Physical Education in Virtual Environment Towards Students Activity in the New Normal Era : Student \& Teacher Perceptions
}

\author{
Robby Septian ${ }^{1, *}$ Yustinus Sukarmin ${ }^{2}$ \\ 1\&2 Universitas Negeri Yogyakarta \\ *Corresponding author.Email: Robbyseptian1875@gmail.com
}

\begin{abstract}
The novel coronavirus disease 2019 (COVID-19) having a major impact on physical activity behaviors globally, including in physical education activities. The primary focus of this study are to identify students' and teachers' perceptions about the virtual physical education learning process during new normal era. This study used a descriptive analysis with survey method. In this study, data were collected from questionnaire to the students and interviews to the teachers. This research instrument in the form of a questionnaire distributed with the help of Google form in August 2020 succeeded in gathering 165 responses from students with different locations. Data analysis techniques using descriptive statistics with percentages. Findings of this study suggests that more attention should be paid to create a virtual learning atmosphere that is more effective to support improving students' physical activity, however, most of the students gave positive responses to the online learning process that has been going on for several months. Specific virtual training during COVID19 outbreak should be further strengthened and improved to protect the mental health of the student, especially to reduce the risk of desease and anxiety.
\end{abstract}

Keywords-Physical activity, covid-19, virtual learning, perception.

\section{INTRODUCTION}

Since the end of 2019, the world has been shocked by the discovery of the virus in China, precisely in the city of Wuhan, which until now has been named Novel Corona Virus Disease 2019 (Covid-19). Corona virus or severe acute respiratory syndrome coronavirus 2 (SARS-CoV-2) is a virus that attacks the respiratory system organs. The Covid-19 virus outbreak has revolutionized life around the world frontally and very rapidly [1]. On January 30, 2020, the world health organization (WHO) declared the covid-19 outbreak a public health emergency and had spread to around 64,000 cases in China at that time [2]. The Covid-19 outbreak that has hit 215 countries in the world, and this presents its own challenges for educational institutions at every level, from elementary school to college. It is important to note that the COVID-19 incubation period in humans presents an average of 5.1 days, and among individuals infected, the meantime of 11.5 days after the infection has been frequently considered to these people start showing some symptoms. Unfortunately, there are no vaccines or medications approved to fight off this new virus, however, many clinical trials have been ongoing for treating people infected by the COVID-19 [3]. To fight Covid19 , the Government has issued an appeal not to crowd, social distancing and maintain physical distance (physical distancing), wear masks and always wash hands. In addition, the Ministry of Education and Culture has also prohibited every educational institution from implementing face-to-face (conventional) learning and ordered each educational institution to conduct lectures or learning virtually based on the Ministry of Education and Culture's Circular Letter No. 1 year 2020. Every educational institution is required to be able to hold all learning activities virtually or online to achieve learning objectives during the Covid-19 pandemic [4]. learning is a process of gaining quality that affects students' ability to obtain information to interact with peers and teachers, and vice versa to participate in learning experiences and acquire knowledge [5].

Meanwhile, online learning is learning that uses internet networks with accessibility, connectivity, flexibility and the ability to generate various types of learning interactions. Research stated by Zhang et al., (2004) shows that the use of the internet and multimedia technology is able to change the way of conveying knowledge and can be an alternative to learning carried out in traditional classrooms [6]. Online learning is learning that is able to bring together students and lecturers to carry out learning interactions with the help of the internet. In line with this, some researchers define online learning as educational material presented on a computer, and others define online instruction as an innovative approach to conveying audience instructions, using the Web as a medium [7]. At the implementation level, online learning requires the support of mobile devices such as smartphones or Android phones, laptops, computers, tablets, and iPhones which can be used to access information anytime and anywhere (Gikas \& Grant, 2013) [8]. Every educational institution during the Covid-19 pandemic needs to carry out strengthening learning 
online. Online learning has become a demand in the world of education since the last few years [9]. The use of mobile technology has a major contribution in educational institutions, including the achievement of distance learning goals [10]. Various media can also be used to support the implementation of online learning. For example, virtual classes use Google Classroom, Edmodo, and Schoology [11], and instant messaging applications such as WhatsApp [12]. Online learning can even be done through social media such as Facebook and Instagram [13]. In line with that, social media plays an important role in enhancing the quality of student collaboration [14]. Of course, when the learning process takes place virtually during this pandemic, teachers have to make new adjustments to virtual teaching styles, and not all teachers are ready for that. Therefore, there are many facilities that can support the implementation of online or virtual learning, even teachers only need to choose the method or application they want to use and adapt it to their learning needs. Besides that, online learning also has its own challenges for teachers and students. Among the challenges that are often experienced by teachers is the lack of knowledge about the application to be used or the unpreparedness of the device to support the implementation of online learning, besides that the teacher is also faced with challenges to attract students to be enthusiastic about participating in class and the instructions given. On the other hand, students also have their own challenges, namely the availability of networks to take part in the virtual learning process, because of course not all students who live in cities with the availability of good networks to support online learning and this should be of particular concern during online learning in this era. pandemic so that in the end all students can receive learning material and do all assignments from the teacher well even though they have to learn distance. One of the subjects at every level of education in Indonesia is Physical Education. Physical Education has most of the practical materials which also require teachers to have high creativity in the implementation of online learning so that it can run well.

Sports and health physical education is one part of the subjects given in senior high schools, junior high schools, and elementary schools to improve human resources, especially in the physical field, fostering a healthy life physically and spiritually leading to complete health in everyday life. Physical education is an educational process that utilizes physical or physical activities that are planned systematically aimed at developing and improving individuals organically, neumuscularly, perceptually, cognitively and emotionally, within the framework of the national education system. The role of physical education is very important for students because through physical education it provides opportunities for students to be able to develop their abilities not only in physical and psychomotor aspects, but also in cognitive and affective aspects. Physical education is the foundation for shaping the character of students by developing a sportsmanship, honesty, discipline and responsibility. In addition, physical education also forms students into intelligent personalities in making decisions in a short time.
Sports and health physical education learning provided in schools has a very important role, which is to provide opportunities for students to be directly involved in various learning experiences through physical activities carried out to improve physical fitness, motor skills, knowledge and emotional intelligence of a person, of course. with direction and monitoring from professional teachers so that students can do physical activity properly and safely [15].

The Proper physical activity has many benefits for students, especially in facing the current pandemic era. The practice of regular physical exercises which may minimize the emergence of problems that directly affect people's behavior should be encouraged, during social isolation in the pandemic period. In this sense, the physical education teacher is classified as the professional who can provide guidance and monitoring, so that the practice of physical exercise is done correctly and safely. Among the strategies used to practice physical exercise in social isolation, classes, and orientations stand out remotely, i.e., physical education teachers provide monitoring and information on how to practice physical exercises through internet [16]. This practice should be part of people's routine, so they can improve cardiorespiratory capacity, reduce the risk of developing chronic diseases, reduce the anxiety, control weight, and improve the quality of life. As is well known, in the pandemic era that has led to selfisolation for even months, body weight is getting out of control if it is not balanced with a healthy lifestyle, one of which is the right physical activity. It is emphasized that several studies have been proving that moderate-intensity physical exercise is effective to increase the immune system, through a reduction in inflammation processes and changes in cell concentrations, thus modulating positively the plasticity of the immune system. These changes may protect the population against severe impairment generated by COVID-19 infection.

In addition, the interpretation of teachers and students in facing virtual learning during this pandemic should be known so that it can be used as an object of examination and material for improvement for the learning process in the future. The interpretation of an object, event or information which is based on the life experience of a person making the interpretation is usually called perception. In general, experts argue that the occurrence of perception is influenced by factors such as experience, background knowledge, physical, social, and cultural backgrounds. Thus, it can be said that perception is the result of one's thoughts from a certain situation. Perception can also be interpreted as something related to the symptoms and experiences you have. The more experience and knowledge in a person, the more and stronger the perception. Apart from science and experience, perception is also influenced by needs and psychological factors. Thus a person's perception of education is different from one another [17]. As the explanation of the challenge of perceptions above, that the perceptions of each person can be different, the perceptions of teachers and students regarding virtual learning systems during the Covid 19 pandemic era need to be studied. 


\section{RESEARCH METHOD}

\section{A. Participant}

Participants in this study were four teachers who came from two senior high schools, namely SMA Negeri 2 and SMA Negeri 8 Kota Pekanbaru. In addition, 165 students who also came from the two schools were involved, each of which three classes were selected. The selection of participants in this study was carried out randomly to teachers and students who had implemented virtual classes for at least one month in physical education subjects.

\section{B. Research design}

The overall research design used in this study is descriptive qualitative [18]. Qualitative descriptive research is a research procedure that produces descriptive data in the form of written or spoken words from people and observable behavior. In line with this, qualitative descriptive research is a summary of a phenomenon that is accurate in daily activities experienced by an individual or group of individuals [19].

\section{Data collection}

The data collection process in this study was divided into two stages, namely the interview stage which was carried out on four participants who were recorded with audio and video, and the second stage was the questionnaire distribution stage through the google form which was distributed using the WhatsApp application by including a link from the google form with easily accessible and filled by students using their respective devices.

\section{Data analysis}

The data analysis process is also divided into two stages, namely the stage of analyzing the results of the interview and the stage of analyzing the results of the questionnaire responses that have been filled in by students to find out the conclusions of teacher and student perceptions about the physical education learning process that has been running virtually.

\section{RESULT}

The results of the research can be described as follows.

\section{A. Results of the perception interview from the physical education teacher}

This section describes five questions that are addressed to physical education teachers in two selected schools, namely Senior High School 2 and 8 in Pekanbaru, Riau, Indonesia. The following is a description of the data of four teachers who acted as participants in this study.
TABLE I. DESCRIPTION DATA OF TEACHERS OR PARTICIPANT

\begin{tabular}{|c|c|c|c|}
\hline Participants & Age & $\begin{array}{c}\text { Length of } \\
\text { teaching }\end{array}$ & Last education \\
\hline P1 & 28 years & 6 years & Undergraduate $(\mathrm{S} 1)$ \\
\hline P2 & 31 years & 8 years & Graduate $(\mathrm{S} 2)$ \\
\hline P3 & 27 years & 5,5 years & Undergraduate $(\mathrm{S} 1)$ \\
\hline P4 & 29 years & 6,5 years & Undergraduate $(\mathrm{S} 1)$ \\
\hline
\end{tabular}

The following is a description of some of the questions and a summary of the responses that the researcher has collected.

1. First question

The first question relates to the readiness of the teacher in facing virtual learning.

Q: Are there any special preparations you did when facing the learning process using this virtual method?

P1: Of course, each teacher must prepare teaching materials that can be given to students online

P2: Yes, any physical education material that can initially be explained directly by practice in school, various videos and teaching materials must be provided to support virtual learning.

P3: Yes, every teacher is required to be ready and have teaching materials that can be virtually accepted by students

P4: Yes, I prepared video and powerpoint teaching materials to make it easier for students to follow the learning process even though they are remotely

2. Second Question

The second question relates to the teacher's interest in virtual or online learning

Q: In your opinion, does this virtual learning help the learning process in this pandemic era run well?

P1: Yes, applications such as zoom and whatsapp really help the implementation of learning even though it is a long distance.

P2: It is quite helpful, the teacher can provide information and students can receive information easily in a fairly short time

P3: Yes, the virtual learning process supported by the right application really helps teachers and students in learning

P4: Yes, various applications are available, both paid and facilitated by the school, all of which can be used to support learning at this time, it is enough to choose according to learning needs so that students have no difficulty in receiving learning

3. Third Question

The third question relates to the teacher's opinion about student interest and involvement.

Q: Do students seem interested during online or virtual learning and follow all instructions well?

P1: During the learning process students seem interested and participate in all learning activities well.

P2: Students' interest is something that is difficult to know, whether they are really interested or just doing their job to take part in virtual learning, but during virtual learning, students can receive the material and assignments well. 
P3: Yes, most of the students followed the whole learning process very enthusiastically and carried out the instructions well.

P4: The instructions that I have given can be accepted and carried out by all students well, the students' interest in the material given is the same

4. Fourth Question

The fourth question relates to the constraints felt by the teacher during online learning.

Q: So far, what are the obstacles that you have experienced during this virtual learning process?

P1: The obstacles experienced were various, ranging from applications that were sometimes difficult to use and the internet network of students which caused not all of them to start learning on time.

P2: Internet network constraints both to teachers and students are the most common.

P3: Most of the problems that often occur are the applications used and the available internet network.

P4: An unstable internet network for students who come from various regions is the most frequent obstacle, but it does not prevent students from learning or getting material

5. Fifth Question

The fifth question relates to the use of online learning as a long-term learning method.

Q: According to you, is this online learning process effective as a long-term learning process method?

P1: In my opinion, for physical education material, it is better to hold teaching and learning processes directly at school.

P2: It will be more effective in the future if the pandemic has subsided using face-to-face learning methods

P3: For subjects that don't really need practice, I think it's okay to do it in the long term

P4: Physical education materials should better use direct learning methods in schools, such as before the pandemic occurred.

\section{B. The results of questionnaire of the student perception}

This section describes the results of the questionnaire responses distributed to 165 participants or students from two schools, namely SMA Negeri 2 and 8 Kota Pekanbaru, Riau, Indonesia. The instrument was distributed to students via a google-form link containing two groups of questions, group I with questions related to the identity of the respondent. Related to name, class, absent number, gender, place of residence, and activities outside of school. The second group consists of 30 question items related to the learning process during the Covid-19 pandemic (March-July 2020) which consists of five aspects, namely mental, intelligence, physical, social and environmental aspects. Following are the results of the questionnaire data that have been compiled and calculated in terms of percentages.
TABLE II DESCRIPTION OF STUDENTS' PERCEPTION ON VIRTUAL LEARNING OF PHYSICAL EDUCATION DURING PANDEMI

\begin{tabular}{|l|c|c|c|c|}
\hline \multirow{2}{*}{ Aspect } & \multicolumn{4}{|c|}{ Student Perception Assessment Category (\%) } \\
\cline { 2 - 5 } & Strongly agree & Agree & Neutral & Disagree \\
\hline Mentally & $14 \%$ & $55 \%$ & $31 \%$ & - \\
\hline Intelligence & $35 \%$ & $30 \%$ & $35 \%$ & - \\
\hline Physical & $24 \%$ & $61 \%$ & $12 \%$ & $3 \%$ \\
\hline Social & $16 \%$ & $37 \%$ & $47 \%$ & - \\
\hline Environment & $10 \%$ & $23 \%$ & $55 \%$ & $12 \%$ \\
\hline
\end{tabular}

\section{DISCUSSION}

Physical education is one of the important subjects at every level of education in Indonesia. Physical education is a part of education that has the same goals as education in general where it is through physical activity that is carried out consciously and systematic. The existence of physical education can make students grow and develop properly from a mental, social and emotional perspective so that they can run in a balanced manner, and can behave in a clean and healthy life in everyday life. The process of implementing Physical Education and Health learning uses more practice in the form of physical activity than theoretical learning. However, since the Covid-19 pandemic hit the world, all activities from various sectors have been hampered, especially in the education sector. The corona virus has had a major impact on the world of education, where with its publication the government's call to jointly fight Covid -19 by avoiding complex activities and maintaining distance [20]. In line with this, since the pandemic hit, the Indonesian government has implemented a virtual distance learning system to reduce cases of the spread of the Covid-19 virus.

Online learning has many forms, each form is good to use as long as it conforms to the principles of quality online learning [21]. As described in Figure 1, the interaction between the three important elements in learning should run well and be related, namely teachers, students and the teaching materials used in the learning process. Based on the interaction scheme, it can be concluded that online learning can be divided into synchronous and ansynchronous forms [22]. Synchronous, which means that the learning process is carried out during normal learning hours so as to allow direct interaction between teachers and students, while asynchronous means that the learning process is carried out outside the usual schedule and at a long distance, so that communication between teachers and students occurs indirectly. Of course, these two processes have their respective advantages and disadvantages and need to be adapted to the learning needs.

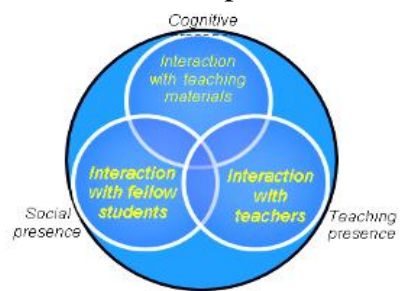

FIGURE 1. ONLINE LEARNING PRINCIPLES 


\section{A. Interview the perceptions of physical education teachers}

This section discusses the results of interviews about the perceptions of high school level physical education teachers regarding online learning that has been going on for several months. Based on the results of the interview, on the first question related to the readiness of the teacher in facing virtual learning, most of the teachers thought they had to prepare written and video teaching materials readily so that students could follow and receive the material smoothly. Online learning relies heavily on good teaching materials that can be easily accepted and understood by all students. In the second question related to teacher interest in virtual or online learning, most of the teachers think that there are already many applications such as WhatsApp and Zoom that make it very easy for teachers to make the online learning process easy and fun. In line with this, the teacher's opinion about the student's interest mentioned in the third question mostly argued that students seemed enthusiastic about doing any given assignment, but there were also those who argued that seeing how much student interest was quite difficult, because sometimes students just wanted to do their obligations and assignments.

In addition, the obstacles that often arise based on the information collected from the teachers are that the connections or networks where each student lives are partly inadequate and result in students not being on time to take lessons, but that is not a significant obstacle. A good internet network is a major supporting factor in the implementation of the online learning process [23]. In addition, the teacher's opinion regarding the application of the virtual learning process for the long term, most teachers wish that physical education learning should be applied as usual, namely face-toface directly in school, because most physical education materials require direct practice to be more effective. Experts in this regard also have the same opinion, that physical education material will be better supported by direct practice, and if through virtual learning, teachers must design teaching materials as creatively as possible so that students can be more interested and can use teaching materials that have been given independently during distance learning [24].

\section{B. Questionnaire of students' perceptions}

This section discusses the results of the questionnaire responses to students' perceptions of online physical education learning which took place from March to July 2020. Questionnaire responses were successfully compiled using the google form link to 165 students spread across 6 classes in 2 schools in Pekanbaru, Riau., Indonesia. Based on student responses to various aspects, namely mental, physical intelligence, environmental and social, Physical aspects (61\%) received the most positive responses followed by mental aspects $(55 \%)$ and intelligence $(30 \%)$. Based on this, it is known that most students think that physical education can help improve their physical and mental health, besides the most important thing is to increase their intelligence with the addition of new knowledge. This proves, online learning plays a major role in student development during a pandemic [25], so it must be carried out as much as possible in order to produce a meaningful learning process for students.

\section{The role of physical activity for students in the pandemic era}

In the era of the Covid-19 pandemic that has hit the world in recent months, everyone is required to maintain their distance [26], avoid crowds and carry out self-isolation in their respective homes. As a result, not a few people are stressed or lose weight ideally due to being at home too long with a lack of physical activity as usual. In this pandemic era, physical education can certainly play a bigger role in increasing students' physical activity. As revealed by the physical education teacher in the interviews that have been conducted, the teachers must act as teachers to provide new information to students as well as being the right tutors for students in directing good activities for students during a pandemic. In line with this, most students also have a positive opinion of learning physical education, even though it is currently practiced virtually, it is able to provide awareness to students about the importance of physical activity and having a healthy lifestyle during a pandemic. Therefore, student learning must be supported by an internet connection and the right devices so that students can continue to update their knowledge [27].

\section{CONCLUSION}

Learning physical education in the virtual midst of a pandemic provides challenges and experiences for students. Based on existing experiences, it is very necessary to know the perceptions of teachers and students after implementing the learning process virtually using various online learning media. Based on the results of research collected through interviews and distributing questionnaires to students, it is known that the teacher does not have too much difficulty in dealing with the learning process virtually, but has a little difficulty in knowing the students' real interest in taking online learning. On the other hand, students do not find it difficult to receive subject matter virtually, but tend to have difficulty in facing various tasks given by the teachers, however, most of the students gave positive responses to the online learning process that has been going on for several months. Physical education plays a very big role in supporting student activities during a pandemic who are required to isolate themselves and maintain a distance. With physical activity that is supported by proper guidance, it can support a healthy lifestyle for students and avoid stress during a pandemic.

\section{ACKNOWLEDGMENT}

Thanks to the Graduate School UNY that has facilitated the funding of this article. Thanks to the reviewers for the suggestions and feedback. 


\section{REFERENCES}

[1] M. Giatman, S. Siswati, I. Yulia Basri. “Online Learning Quality Control in the Pandemic Covid-19 Era in Indonesia," Journal of Nonformal Education, vol. 6, no. 2, pp. 168-175, 2020.

[2] S. Wang, B. Kang, J. Ma, X. Zeng, M. Xiao and J. Guo, "A deep learning algorithm using $\mathrm{CT}$ images to screen for corona virus disease (COVID-19)", pp. 1-26, 2020.

[3] S. G. Rosa, W. C. Santos, Clinical trials on drug repositioning for COVID-19 treatment, Rev Panam Salud Publica, 2020.

[4] S. L. Schneider, \& M. L. Council, "Distance learning in the era of COVID-19”, Archives of Dermatological Research, pp. 1-2, 2020.

[5] M. A. Bhat, "Understanding the Learning Styles and its Influence on Teaching/Learning Process", International Journal of Education and Psychological Research, vol. 3, no. 1, pp. 14-21, 2014.

[6] Zhang, D., Zhao, J. L., Zhou, L., \& Nunamaker, J. F, Can e-learning replace classroom learning? Communications of the ACM, vol. 47, no. 5, pp. 75-79, 2004

[7] T. Anderson, \& D. Garrison, "Learning in a networked world: New roles and responsibilties. In Distance Learners in Higher Education Institutional responses for quality outcomes" Madison,Wi.: Atwood. 1998.

[8] J. Gikas, \& M. M. Grant, "Mobile computing devices in higher education: Student perspectives on learning with cellphones, smartphones \& social media", Internet and Higher Education, vol 19, pp. 18-26, 2013.

[9] W. He, G. X, \& S. Kruck, "Online IS Education for the 21st Century", Journal of Information Systems Education, vol. 25, no. 2, pp. 101-106, 2014.

[10] A. T. Korucu, \& A, Alkan, "Differences between m-learning (mobile learning) and elearning, basic terminology and usage of m-learning in education", Procedia - Social and Behavioral Sciences, vol. 15, pp. 1925-1930, 2011

[11] M. A. S. Enriquez, "Students ' Perceptions on the Effectiveness of the Use of Edmodo as a Supplementary Tool for Learning”. DLSU Research Congress, 2014

[12] S. So, "Mobile instant messaging support for teaching and learning in higher education", Internet and Higher Education, vol. 31, pp. 32-42, 2016

[13] V. Kumar, \& P. Nanda, "Social Media in Higher Education. International", Journal of Information and Communication Technology Education, vol. 15, no.1, pp. 95-108, 2018.

[14] S. Siddiqui, \& T. Singh, "Social media its impact with positive and negative aspect"s. International Journal of Computer Applications Technology and Research, vol.5, no.2, pp.71-75, 2016.
[15] E. S. Filho, A. L. Teixeira , S. Xavier, B. Júnior, R. Barbosa, J. A Albuquerque, Physical education role during coronavirus disease 2019 (COVID-19) pandemic Physical education and COVID-19, Brief Communication, vol. 26, no. 2, pp. 1-2, 2020.

[16] L. Goossens, R. De Ridder, G. Cardon, E. Witvrouw, R. Verrelst, D. De Clercq, "Injury prevention in physical education teacher education students: lessons from sports", A systematic review. European Physical Education Review, vol. 25, no. 1, pp. 156-173, 2019.

[17] L. M. Cakrawati, "Students' perceptions on the use of online learning platforms in efl classroom", vol. 1, no. 1, pp. 22-30, 2017.

[18] J.W. Creswell, Qualitative inquiry and research design: Choosing among five traditions (2nd ed.), Thousand Oaks, CA: Sage. 2007.

[19] V. A. Lambert, "Qualitative descriptive research; an acceptable design", Pacific Rim International Journal of Nursing Research, vol. 16, no. 4, pp. 255-256, 2012.

[20] C. Annalaura, F. Ileana, L. Dasheng, \& V. Marco, Making waves: Coronavirus detection, presence and persistence in the water environment: State of the art and knowledge needs for public health. Water Research, 115907, 2020.

[21] M. Giatman, S. Siswati, I. Yulia Basri. “Online Learning Quality Control in the Pandemic Covid-19 Era in Indonesia," Journal of Nonformal Education, vol. 6, no. 2, pp. 168-175, 2020.

[22] K. Seluakumaran, F. Jusof, R. Ismail, \& R. Husain, "Integrating an open source course management system (Moodle) into the teaching of a firstyear medical physiology course: A case study", Advances in Physiology Education, Vol. 35, no. 4, pp. 369-377, 2011.

[23] S. Bell, C. Douce, S. Caeiro, A. Teixeira, R. Aranda, \& D. Otto, "Sustainability and distance learning: a diverse European experience", Open Learning, vol. 32, no. 2, pp. 95-102, 2017.

[24] Y. C. Kuo, A. E. Walker, K. E. Schroder, \& B. R. Belland, "Interaction, internet self-efficacy, and self-regulated learning as predictors of student satisfaction in online education courses", Internet and Higher Education, vol. 15, no. 1, pp. 35-50, 2014.

[25] W. Wargadinata, I. Maimunah, E. Dewi \& Z. Rofiq, "Student's responses on learning in the early covid-19 pandemic", Tadris: Journal of Education and Teacher Training, vol 5, no. 1, pp. 141-153, 2020.

[26] R. Stein, "Covid-19 and rationally layered social distancing", International Journal of Clinical Practice, Vol. 74, no. 7, pp. 1-3, 2020.

[27] R. H. Kay \& S. Lauricella, "Exploring the Benefits and Challenges of Using Laptop Computers in Higher Education Classrooms: A Formative Analysis", Canadian Journal of Learning and Technology /La Revue Canadienne de l'apprentissage et de La Technologie, vol. , no. , pp. , 2011 